\title{
The Movement of Boron Compound by Infusion Method and Combination of Injection and Bandage-Wrapping ${ }^{1}$
}

\author{
Ratih DAMAYANTI ${ }^{2, \uparrow} \cdot$ Evi SRIBUDIANI ${ }^{3} \cdot$ Sonia SOMADONA $^{3} \cdot$ Djarwanto $^{2} \cdot$ \\ Didi TARMADI ${ }^{4} \cdot$ Yusup $\mathrm{AMIN}^{4} \cdot$ Sulaeman $\mathrm{YUSUF}^{4} \cdot$ Esti Rini SATITI $^{2} \cdot$ \\ Wa Ode Muliastuty ARSYAD ${ }^{2} \cdot$ Rudianda $\operatorname{SULAEMAN}^{3} \cdot$ Syafrinal $^{3} \cdot$ \\ Dwi Ajias PRAMASARI ${ }^{4}$
}

\begin{abstract}
The existing preservation methods are difficult to be applied to a large dimension log which is needed for making traditional wooden ship 'Jalur' in Riau Province. Novel techniques to provide the use of readily available species to replace traditional species alternative were investigated. These included infusion and a combination of injection and bandage-wrapping methods for preserving living trees of Balam (Macaranga conifera (Rchb.f. \& Zoll.) Müll.Arg.) and Bintangor (Calophyllum soulattri Burm.f.). Water-based boron compounds were applied as wood preservatives. In total, 18 discs from the bottom, middle, and top of four trees and two controls were used. Trees undergoing treatment were also used to see how wood anatomical structure might affect the boron penetration. The overall aim was to identify the best method for use in Jalur manufacturing. The results showed that in infused Balam tree where the hose position for the preservative intake was deep (10-15 cm from the bark), no boron compound was observed in the outer sapwood. Combination of injection and bandage-wrapping method gave higher percentage of boron penetration at bottom and middle of Balam tree. However, infused Bintangor showed 100\% boron penetration. The larger vessel diameter, the absence of tyloses, and the simple perforation plates in Bintangor wood were likely to have contributed to the higher penetration of boron. The combination of bandage-wrapping and infusion, or alternatively by infusing the living trees close to the bark, and at as low as position in the stem gives better protection when treatments are applied to living trees.
\end{abstract}

Keywords: living tree preservation, wooden ship, cell dimension, axial direction, radial movement, sap flow

\section{INTRODUCTION}

'Pacu Jalur' is a rowing boat racing competition using traditional wooden boats. The boat, named 'Jalur', is made from a big and long log. This racing competi- tion is a cultural tradition of people in Kuantan Singingi Regency, Riau Province, Indonesia, and become important because the performance of 'Jalur' reflects the community's identity (Sribudiani et al., 2019). Wood used for 'Jalur' is only available from natural forests.

\footnotetext{
${ }^{1}$ Date Received December 4, 2019, Date Accepted June 11, 2020

${ }^{2}$ Forest Products Research and Development Centre - Research, Development and Innovation Agency, Indonesian Ministry of Environment and Forestry, Bogor, 16680, Indonesia

${ }^{3}$ Forestry Department, Faculty of Agriculture, Riau University, Pekanbaru 28293, Indonesia

${ }^{4}$ Research Center for Biomaterials, Indonesia Institute of Sciences, Cibinong, Bogor, 16911, Indonesia

$\dagger$ Corresponding author: Ratih DAMAYANTI (e-mail: ratih_turmuzi@yahoo.com, ORCID: 0000-0002-7994-7955)
} 
Ratih DAMAYANTI $\cdot$ Evi SRIBUDIANI $\cdot$ Sonia SOMADONA $\cdot$ Djarwanto $\cdot$ Didi TARMADI $\cdot$ Yusup AMIN $\cdot$ Sulaeman YUSUF $\cdot$ Esti Rini SATITI $\cdot$ Wa Ode Muliastuty ARSYAD $\cdot$ Rudianda SULAEMAN $\cdot$ Syafrinal $\cdot$ Dwi Ajias PRAMASARI

The people of Kuantan Singingi Regency usually use commercially durable and strong wood species from Dipterocarpaceae family. In the traditional Jalur making, the wood has minimum diameter of $100 \mathrm{~cm}$ and minimum length of $30 \mathrm{~m}$ as it has to accommodate 70 rowers.

In the last five years, desirable timber for Jalur manufacturing is scarce and difficult to obtain. The difficulties in sourcing raw materials could result in an undesirable loss of community traditions. For that reason, alternative wood species need to be found to substitute existing ones to ensure that community traditions can be maintained. Among some alternative wood species which are still commonly available in the Kuantan Singingi Regency are Balam (Macaranga conifera (Rchb.f. \& Zoll.) Müll.Arg.) and Bintangor (Calophyllum soulattri Burm.f.) (Sribudiani et al., 2019). However, these common species have low natural durability (Classes II-IV), with a service life ranging from 2-5 years (Abdurrohim et al., 2006; Martawijaya et al., 2005; Seng, 1990; Soerianegara and Lemmens, 1994; Sosef et al., 2008). The use of these wood species particularly in the water reduce their service life. Thus, to improve the wood durability, a preservative treatment is needed. Fadillah et al. (2014) and Hadi et al. (2018) reported that preservative agents increased the service life of the timber and improved natural durability of woods against bio-deterioration attacks.

It has been well known that there are two preservative treatment processes, i.e. pressure impregnation and non-pressure treatment. The preservative treatment by pressure is applied for water solution of inorganic preservative, i.e. boron (Obanda et al., 2008; Rabbi et al., 2015). This method is very effective to obtain high retention for inorganic preservative; however, the disadvantages of this process are high initial costs for the equipment as well as the energy costs (Rabbi et al., 2015). The preservative treatment by non-pressure is applied for water/oil solution of preservative agents by dipping, brushing or spraying, and soaking. The advantage of this method is very easy in application, but its disadvantage is not suitable for boron due to such preservative is easy to leach (Kartal et al., 2009; Rabbi et al., 2015). In fact, boron preservative is still used in Indonesia due to low cost and available in the market. Moreover, the advantage of boron salts is that they are soluble in the sap of living trees (Walker et al., 1993). Therefore, in this study, we used boron preservatives to increase the durability of Balam and Bintangor for "Jalur" manufacturing.

As mentioned above, "Jalur" is manufactured using a big and long log, thus, it is needed to find a suitable method to preserve the woods for "Jalur". An earlier study reported that non-pressure treatment, for example diffusion, is carried out in the green condition (sap replacement), but it is difficult to be applied to a largedimension members $(100 \mathrm{~cm}$ in diameter and $30 \mathrm{~m}$ in length) as a large dip tank is required. Diffusion treatment can be applied as part of the natural sapflow processes (Hansman et al., 2002). Modern pressure treatment plants can accommodate the process, but heavy equipment is needed to lift the tree-stems. In preserving a dry log when the trees has already been cut and begun to dry out, impregnation of the wood with preservatives can cause large cracks, and these cracks tend to extend deeper than the preservative penetration (Pang et al., 2017). Economically, the process described is unreliable and expensive. A possible alternative approach is to apply chemical treatment directly to the living tree. Such a preservation method has not previously been attempted nor can it be applied in tree size material using current technology. The aim of this study was to investigate treatment by infusion and a combination of injection and bandage-wrapping to treat chemically Balam and Bintangor standing trees.

Various factors can influence the success of the preservation treatment. The penetration of the preser- 
The Movement of Boron Compound by Infusion Method and Combination of Injection and Bandage-Wrapping

vative used and the anatomical structure of the wood are of importance. Boron compounds have long been used to preserve wood and have proven effective in increasing wood durability (Cahyono et al., 2020). Boron compounds were tested because the preservative has good efficacy when combined with wood vinegar (Arsyad et al., 2019), where a standing tree is assumed to contain extractive compounds that are acidic.

The anatomical structure of a wood is important in determining the wood porosity, that is the ease of fluid flow due to a pressure gradient (Panigrahi et al., 2018; Walker et al., 1993). Preservation is one of the most important practices in wood processing technology to enhance wood longevity in hostile environments; it mostly depends on the wood porosity (Panigrahi et al., 2018). The main flow paths are in the axial direction and this is provided by the wood-vessels, their size, number, and degree of occlusion. The frequency and transverse dimensions of vessels have a significant effect on wood porosity (Baraúna et al., 2014). The vessel cells in hardwoods facilitate sap conduction (Panshin et al., 1964), and when the preservative treatment is applied to the living tree the vessels provide the pathway to distribute the preservative. Sap ascending via the vessels passes from vessel element to the next vessel element through openings or perforations (Walker et al., 1993).

Degree of permeation of treatment compounds is species dependent and is primarily axial (Panigrahi et al., 2018). This study was conducted to investigate factors which have a bearing on the treatment process of Balam and Bintangor in living trees. Initial experiments were conducted on smaller trees to find the best treatment regime prior to its application to larger trees for Jalur manufacturing.

\section{MATERIALS and METHODS}

\subsection{Preservative treatments: Infusion and combination of injection and bandage-wrapping}

Two standing trees of Balam (Macaranga conifera (Rchb.f. \& Zoll.) Müll.Arg.) and Bintangor (Calophyllum soulattri Burm.f.) were treated with a boron compound using the infusion method (Fig. 1) and combination of injection and bandage-wrapping methods (Fig. 2). In the

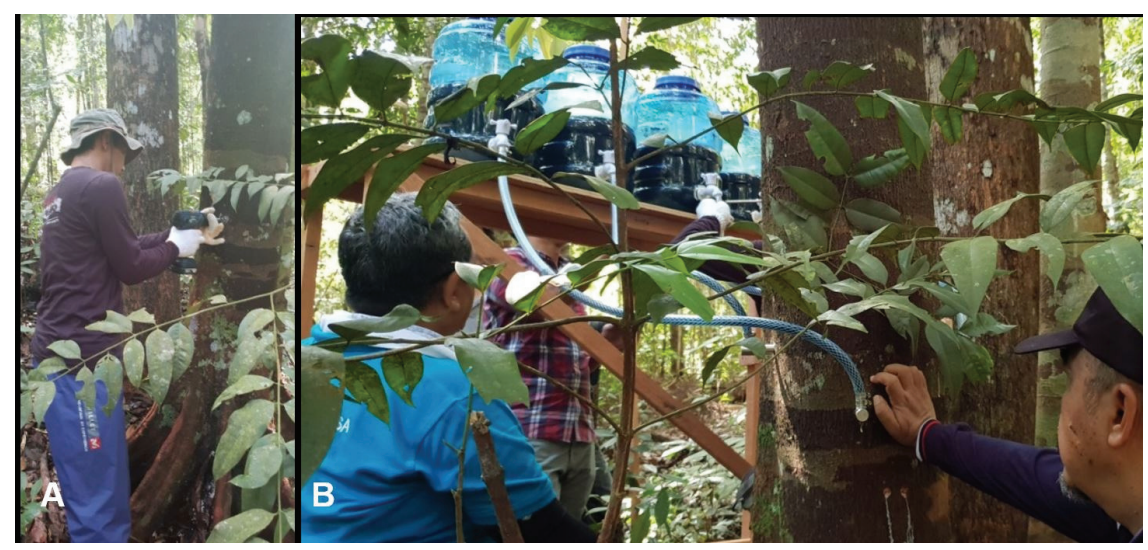

Fig. 1. Treatment of standing trees using infusion method; four $15 \mathrm{~mm}$ diameter holes were made at three meters above ground for injecting preservative into the live tree at depth 10-15 cm (A), preservative (boron) solution was introduced using plastic hoses into the holes (B). 
Ratih DAMAYANTI $\cdot$ Evi SRIBUDIANI $\cdot$ Sonia SOMADONA $\cdot$ Djarwanto $\cdot$ Didi TARMADI $\cdot$ Yusup AMIN $\cdot$ Sulaeman YUSUF . Esti Rini SATITI $\cdot$ Wa Ode Muliastuty ARSYAD $\cdot$ Rudianda SULAEMAN $\cdot$ Syafrinal $\cdot$ Dwi Ajias PRAMASARI
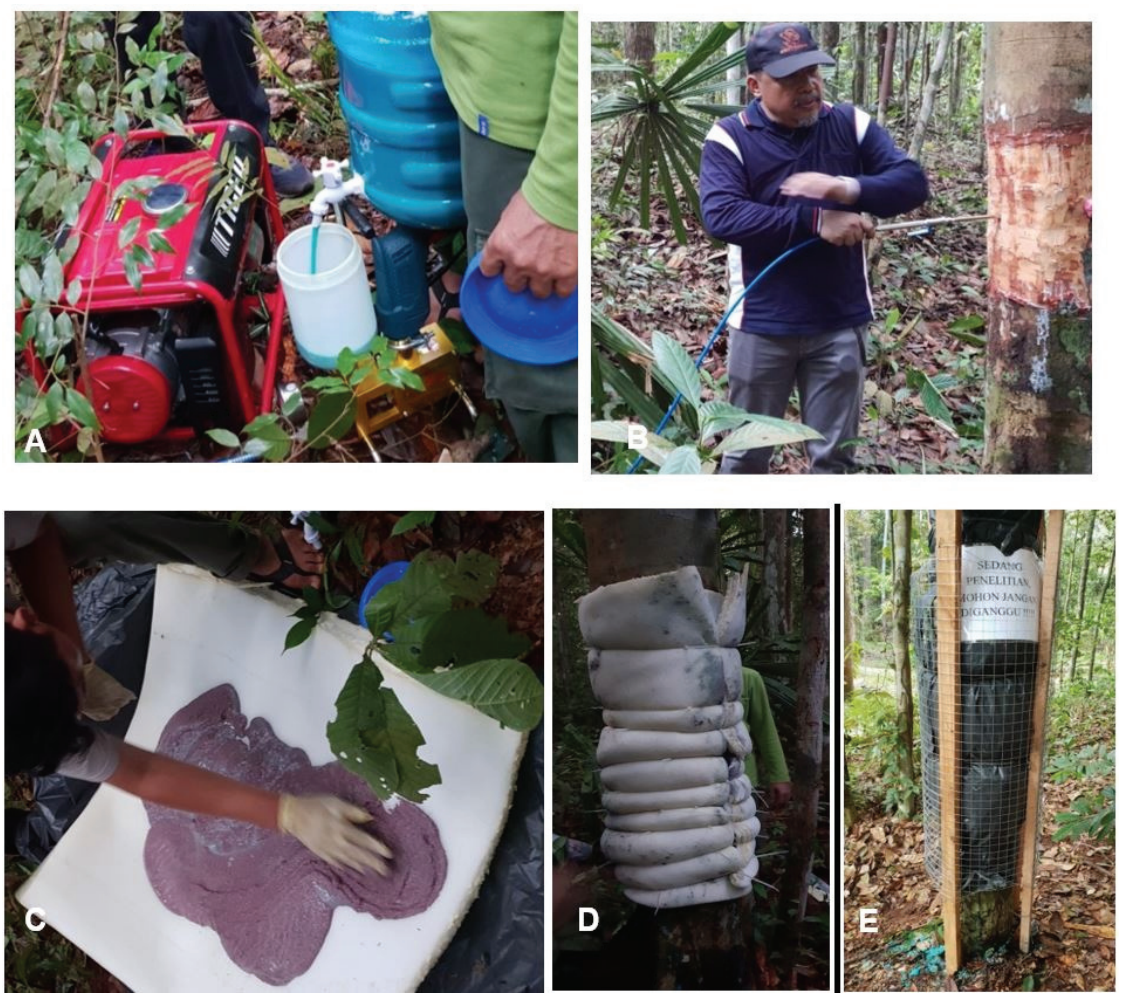

Fig. 2. Treatment of standing tree using a combination of injection (above) and bandage-wrapping methods (below); preservative injection is applied to the tree stem under pressure. A: preparation of preservative solution; B: injection of preservative solution into the living tree using a pump; $\mathrm{C}$ and $\mathrm{D}$ : preservative solution for bandage-wrapping mixed with CMC (carboxymethyl cellulose) is applied to the living tree; E: Experimental trees protected with wire.

infusion process, the boron compound was introduced with a blue dye to indicate the degree of penetration. Details of both techniques will be presented elsewhere. Research was carried out at TAHURA Minas Siak Regency for the injection and bandage-wrapping approaches, while the infusion methods were tested at Hutan Larangan Adat Rumbio in Kampar Regency. Preservative treatments at both locations were conducted from April to August 2019, and wood anatomical study was carried out in September 2019 at the Lignocellulose Anatomy Laboratory, Forest Products Research and Development Centre. Each species was represented by three trees.

\subsection{Materials preparation}

After felling, the sample trees were cross cut one meter from the base to the top (clear of branches), in order to investigate the axial movement. Infused trees were cut after four months from the start of the treatment (July 2019), that was when the solution was completely absorbed, and the preservative liquid of the infused stems was indicated by the colour indicator in trees. The injected and bandage-wrapping treated trees were cut after five months treatment (August 2019), that was when the trees were initially non-living as indicated by the shed leaves. 


\subsection{Detection of boron penetration and retention}

Three discs were taken each from the bottom, middle, and top for anatomical testing. Boron penetration was detected using two reagents: 1) $2 \%$ curcuma in ethanol, and 2) $20 \% \mathrm{HCl}$ in ethanol saturated with salicylic acid (usually 6-9 grams per $100 \mathrm{ml}$ ) (Djarwanto and Sudradjat, 2002). The first reagent was sprayed onto the transverse surface and temporarily aerated, then followed by spraying with the second reagent until both regents were dry. Boron penetration was indicated by the presence of orange to red-purple colour on the disk surface. To minimize the human error, automatic image processing was used to determine the proportion of stain using Image $\mathbb{\circledR}$ freeware routines.

\subsection{Wood anatomy observation and measurement}

The anatomical structure observations were made along three radial positions, the sapwood, the heartwood, and the transition between them. Wood anatomical observation was made by examining thin sections that were prepared according to the botanical microtehnique by Sass (1961) in Damayanti (2019). The anatomical characteristics of wood both qualititavely and quantitatively were examined based on features recommended by the International Committee of the Association of Wood Anatomists (Wheeler et al., 1989). Cell dimension measurements (vessel lenght) were carrried out on macerated cells prepared by modified Franklin method as detailed in Damayanti (2016).

\subsection{Data analysis}

A total of 135 single vessel cells in each tree were measured using software provided by Zeiss Axio Imager microscope. Measurement data were graphed (Fig. 4, Fig. 6, and Fig. 7).

\section{RESULTS and DISCUSSION}

\subsection{Boron penetration and retention}

Penetration of boron compounds from infused trees (Balam) is presented in Fig. 3. The dye acted as an indicator for the boron solution distribution in the tree. The preservative appeared to penetrate both sapwood and heartwood of the Balam stem at the bottom level (P1), showing that the preservative accumulated at the tree base. It indicated that there was a downward flow below the point where the liquid was infused. On the upper disc at bottom (P2), the preservative is found in sapwood, but stopped at the transition zone. The transition zone is defined as 'a narrow, pale-colored zone surrounding some heartwoods and injured regions, often containing living cells, usually devoid of starch, often impermeable to liquids, with a moisture content lower than the sapwood and sometimes also the heartwood' (Hillis 1987). Barnacle and Ampong (1974) observed preservative problems associated with the occurrence of a relatively wide zone of intermediate wood nearly impermeable to treatment in fence posts cut from $15 \mathrm{~cm}$ in diameter of 15-year old un-pruned plantation grown Tectona grandis trees.

However, the most outer zone of the disc (all sapwood) was devoid of colour indicating that there was no outflow from the infusion position toward the bark direction. A similar pattern was observed in discs from the middle and the top (branch-free) portions of trees. Preservative was also observed in the pith zone.

The result shown in the disks was consistent with the infiltration pattern in the sawn timber in Fig. 3. The sawn timber in each illustration shows the position from the pith to the bark (right to the left). The right-most and left-most of the sawn timbers are near the bark. Away from the pith, the dye was not observed; suggesting that the outer part of the stem, the sapwood was clear, i.e., without preservative. It is generally expected that functional sapwood is likely to be 
Ratih DAMAYANTI $\cdot$ Evi SRIBUDIANI $\cdot$ Sonia SOMADONA $\cdot$ Djarwanto $\cdot$ Didi TARMADI $\cdot$ Yusup AMIN $\cdot$ Sulaeman YUSUF . Esti Rini SATITI $\cdot$ Wa Ode Muliastuty ARSYAD $\cdot$ Rudianda SULAEMAN $\cdot$ Syafrinal $\cdot$ Dwi Ajias PRAMASARI
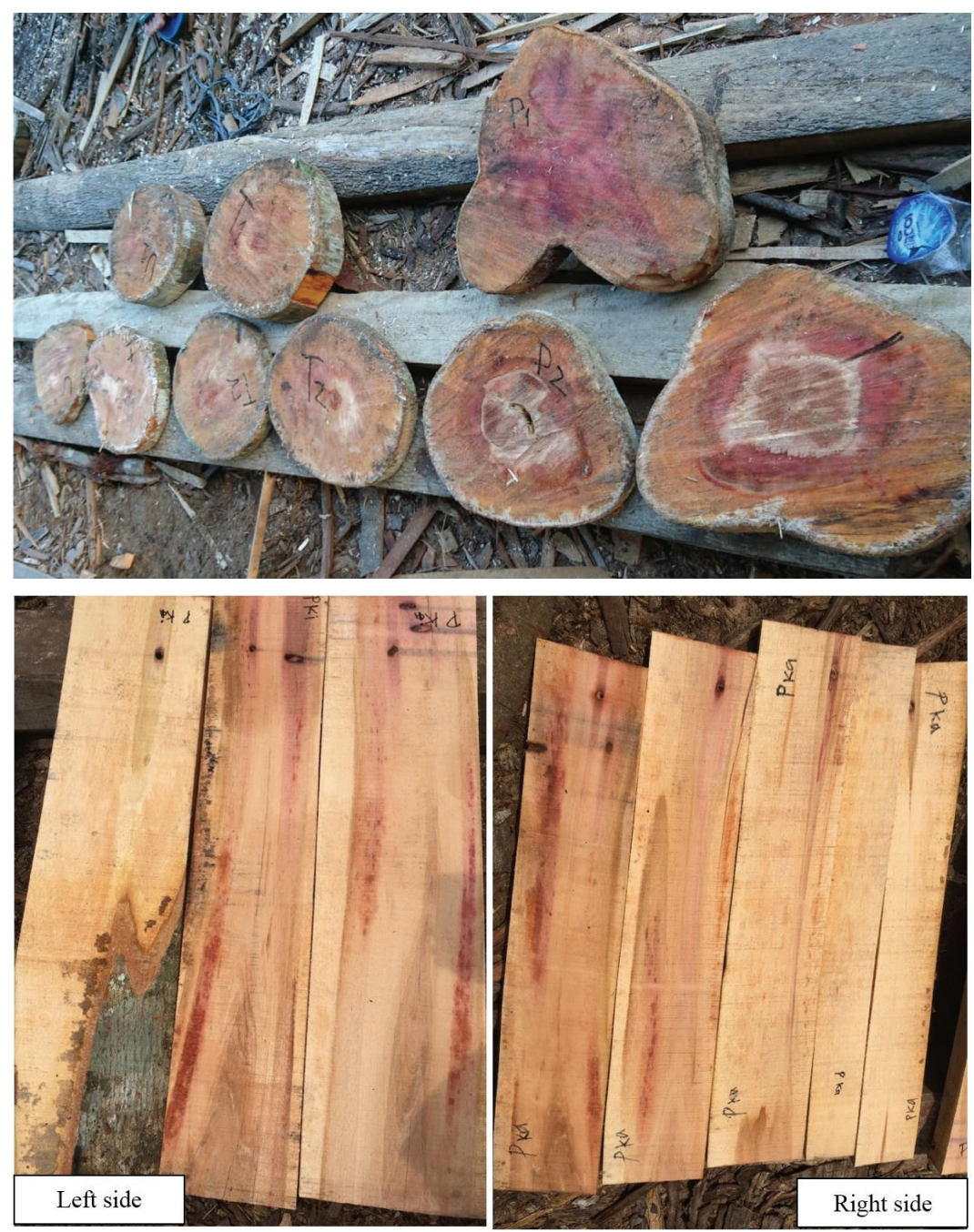

Fig. 3. Pattern of preservative penetration in infused Balam tree.

fully penetrated by the boron solution and that the heartwood of most timber species is impermeable thereby leading to limited mass flow during preservation. It may be that the normally conductive sapwood was not functional or that the treatment material migrated to the tree-leaves during continued sap flow. Thus, it is worth to test the boron concentration in the leaves. It is possible the remaining material was retained in the non-sapwood zones.
A stronger indication was no radial outflow occurred from the injection position where the boron solution was infused, $10-15 \mathrm{~cm}$ depth, to the bark direction. From the appearance of the transverse section, the heartwood showed extremely low permeability; the rate of liquid flow was low being consistent with the findings of Ellwood and Ecklund (2020). Ray tissue is not particularly efficient in radial flow (Walker et al., 1993). Moreover, Mihilaka Forestry 


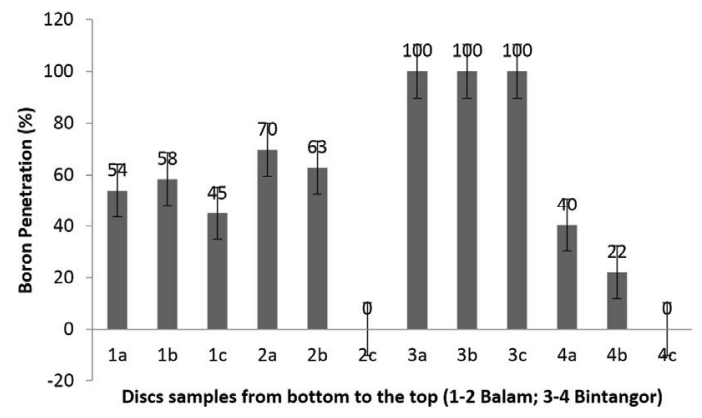

Fig. 4. Penetration of Boron compound in Balam and Bintangor trees by infusion and combination of injection and bandage-wrapping methods at different heights.

Remarks: 1a=Infused Balam (H $1 \mathrm{~m}) ; 1 \mathrm{~b}=\operatorname{Infused~Balam~}(\mathrm{H}$ $7 \mathrm{~m}) ; 1 \mathrm{c}=$ Infused Balam (H $14 \mathrm{~m}) ; 2 \mathrm{a}=$ Bandaged Balam $(\mathrm{H}$ $1 \mathrm{~m}) ; 2 \mathrm{~b}=$ Bandaged Balam $(\mathrm{H} 5 \mathrm{~m}) ; 2 \mathrm{c}=$ Bandaged Balam (H $12 \mathrm{~m}) ; 3 \mathrm{a}=$ Infused Bintangor $(\mathrm{H} 1 \mathrm{~m}) ; 3 \mathrm{~b}=$ Infused Bintangor $(\mathrm{H} \quad 4 \mathrm{~m})$; 3c=Infused Bintangor $\left(\begin{array}{llll}\mathrm{H} & 7 & \mathrm{~m}\end{array}\right)$; $4 \mathrm{a}=$ Bandaged Bintangor ( $\mathrm{H} 2 \mathrm{~m}$ ); $4 \mathrm{~b}=$ Bandaged Bintangor (H $6 \mathrm{~m}) ; 4 \mathrm{c}=$ Bandaged Bintangor $(\mathrm{H} 10 \mathrm{~m}) ; \mathrm{H}=$ Height (the proportional vertical position of the disc at bottom, middle and top).

Service stated that preservatives can only get in from the outside (Forestry Education Web Service, 2020).

Figs. 4 and 5 show the penetration of Boron compound in Balam and Bintangor trees by infusion and combination of injection and bandage-wrapping methods at different tree heights bottom, middle, and top of the tree. In the same species Balam but using a different treatment method (combination of injection and bandage-wrapping), the percentage of boron penetration was higher at the bottom and middle areas than that by the infusion method probably because the preservative liquid uptake started from outside the xylem (See Fig. 5A and Fig. 5B). On the other hand, treatment compounds could not reach the top part of the tree that is $12 \mathrm{~m}$ above ground (see Fig. 4), probably because during the five months treatment, the boron compound in the bandage-wrapping was drying out. Scrapping away the phloem as shown in Fig. 2 also gave rise to undesirable stem girdling which probably led to a decrease the moisture content from the drying out (Basri et al., 2015). This was confirmed by the tree death within five months from the start of the treatment. However, this procedure may will be useful if there is a need to process dry logs for Jalur manufacturing. As sapwood is the least durable, thus by combining infusion and bandage-wrapping or alternatively infusing living trees from the bottom near the bark will work better to afford protection for Balam wood.

Different behaviour was observed in Bintangor trees. The infusion method gave $100 \%$ boron penetration from bottom to the top part of trees. However, the combination of injection and bandage-wrapping gave rise to lower penetration, approximately $20 \%$, and with irregular penetration. The low penetration of injected and bandage-wrapped Balam tree at different heights of the trees might be caused by the drying out of the boron paste during the treatment.

In the axial direction, the preservative was found at the base and along the length of the tree including the top. The high penetration of the bottom disc was lower than the point of injection or infusion. It is most likely that the low application is best explained by a reduction of back sap flow hydraulic pressure, i.e., the higher the injection point is the less treatment material is likely flow backward against the sap flow pressure (Ilic, personal communication, May 15, 2020). The upward movement of compounds occured with the tree-sap flow. Further most other flow and retention is likely to depend on the long-time diffusive process once the material has been injected (Ilic, personal communication, May 15, 2020).

\subsection{The effects of anatomical structure of Balam and Bintangor on penetration}

Several factors influence the penetration and retention of chemical preservatives in wood. Penetration depth of treated wood is influenced by the size and 
Ratih DAMAYANTI $\cdot$ Evi SRIBUDIANI $\cdot$ Sonia SOMADONA $\cdot$ Djarwanto $\cdot$ Didi TARMADI $\cdot$ Yusup AMIN $\cdot$ Sulaeman YUSUF . Esti Rini SATITI $\cdot$ Wa Ode Muliastuty ARSYAD $\cdot$ Rudianda SULAEMAN $\cdot$ Syafrinal $\cdot$ Dwi Ajias PRAMASARI
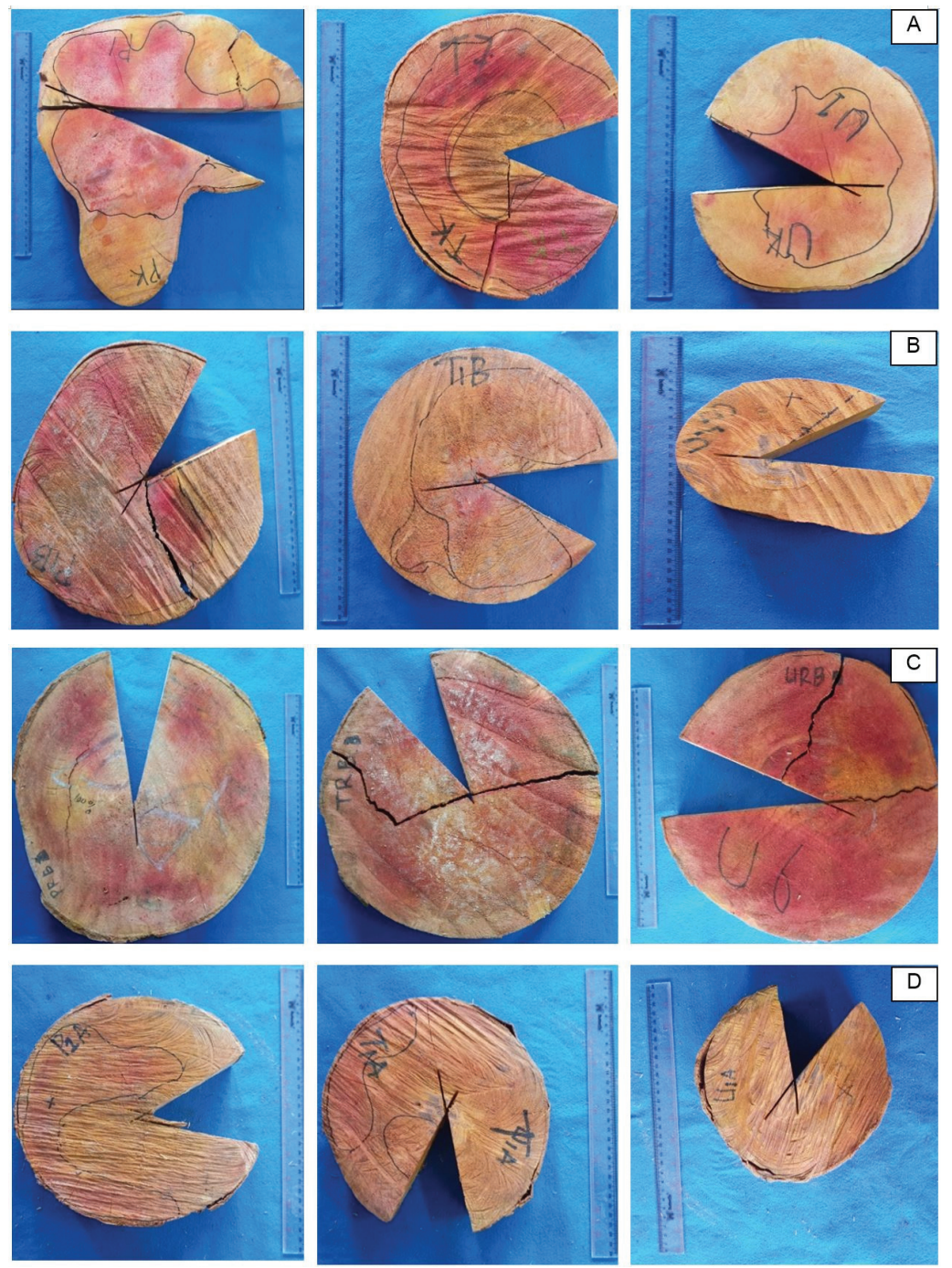

Fig. 5. Penetration of Boron compound in Balam and Bintangor trees by infusion and combination of injection and bandage-wrapping methods at different heights (bottom, middle and top).

A. Infused Balam; B. Bandaged Balam; C. Infused Bintangor; D. Bandaged Bintangor

number of vessels and the degree of vessel occlusion by tyloses or other vessel infiltrations (Ellwood and Ecklund, 2020; Ra, 2019; Walker et al., 1993). Table 1 presents the anatomical structures of Balam and Bintangor wood, and Fig. 6 and Fig. 7 present the vessel dimensions of both species. The critical differences of wood anatomical structure of Balam (Macaranga conifera (Rchb.f. \& Zoll.) Müll.Arg.) and Bintangor (Calophyllum soulattri Burm.f.) are to do with hydraulic properties of the vessels acting as conduits. In this case, the vessels of Balam are diffuse, and commonly arranged in radial multiples of four or more with simple and scalariform 
The Movement of Boron Compound by Infusion Method and Combination of Injection and Bandage-Wrapping

Table 1. Anatomical structure of Balam (Macaranga conifera (Rchb.f. \& Zoll.) Müll.Arg.) and Bintangor (Calophyllum soulattri Burm.f.)

\begin{tabular}{|c|c|c|c|}
\hline $\begin{array}{l}\text { IAWA } \\
\text { Code }\end{array}$ & $\begin{array}{ll} & \text { Balam } \\
\text { (Macaranga conifera } & \text { (Rchb.f. \& Zoll.) Müll.Arg.) }\end{array}$ & $\begin{array}{l}\text { IAWA } \\
\text { Code }\end{array}$ & $\begin{array}{c}\text { Bintangor } \\
\text { (Calophyllum soulattri Burm.f.) }\end{array}$ \\
\hline \multicolumn{4}{|c|}{ Growth Rings } \\
\hline 1 & Growth ring boundaries distinct & (1) & Growth ring boundaries distinct \\
\hline 2 & Growth ring boundaries indistinct or absent & 2 & Growth ring boundaries indistinct or absent \\
\hline \multicolumn{4}{|l|}{ Vessels } \\
\hline \multirow[t]{3}{*}{5} & Wood diffuse-porous & 5 & Wood diffuse-porous \\
\hline & & 7 & Vessels in diagonal and / or radial pattern \\
\hline & & 9 & Vessels exclusively solitary ( $90 \%$ or more) \\
\hline 10 & Vessels in radial multiples of 4 or more common & & \\
\hline 13 & Simple perforation plates & 13 & Simple perforation plates \\
\hline \multirow[t]{3}{*}{14} & Scalariform perforation plates & & \\
\hline & & 20 & Intervessel pits scalariform \\
\hline & & 21 & Intervessel pits opposite \\
\hline 22 & Intervessel pits alternate & 22 & Intervessel pits alternate \\
\hline 23 & Shape of alternate pits polygonal & & \\
\hline 30 & $\begin{array}{l}\text { Vessel-ray pits with distinct borders; similar to } \\
\text { intervessel pits in size and shape throughout the } \\
\text { ray cell }\end{array}$ & & \\
\hline 31 & $\begin{array}{l}\text { Vessel-ray pits with much reduced borders to } \\
\text { apparently simple: pits rounded or angular }\end{array}$ & & \\
\hline 32 & $\begin{array}{l}\text { Vessel-ray pits with much reduced borders to } \\
\text { apparently simple: pits horizontal (scalariform, } \\
\text { gash-like) to vertical (palisade) }\end{array}$ & 32 & $\begin{array}{l}\text { Vessel-ray pits with much reduced borders to apparently } \\
\text { simple: pits horizontal (scalariform, gash-like) to vertical } \\
\text { (palisade) }\end{array}$ \\
\hline 42 & Vessel diameter $100-200 \mu \mathrm{m}$ & 42 & Vessel diameter $100-200 \mu \mathrm{m}$ \\
\hline \multirow[t]{2}{*}{43} & Vessel diameter $>=200 \mu \mathrm{m}$ & 43 & Vessel diameter $>=200 \mu \mathrm{m}$ \\
\hline & Mean vessel diameter $212 \pm 49 \mu \mathrm{m}$ & & Mean vessel diameter $271 \pm 74 \mu \mathrm{m}$ \\
\hline 46 & $<=5$ vessels per square millimetre & 46 & $<=5$ vessels per square millimetre) \\
\hline \multirow[t]{2}{*}{47} & $5-20$ vessels per square millimetre & & \\
\hline & Mean vessel per square millimetre: $6.7 \pm 0.5$ & & Mean vessels per square millimetre: $4 \pm 1$ \\
\hline 53 & Vessel length: $350-800 \mu \mathrm{m}$ & 53 & Vessel length: $350-800 \mu \mathrm{m}$ \\
\hline \multirow[t]{2}{*}{54} & $>=800 \mu \mathrm{m}$ & 54 & $>=800 \mu \mathrm{m}$ \\
\hline & Mean vessel length $990 \mu \mathrm{m}$ & & Mean vessel length $890 \mu \mathrm{m}$ \\
\hline \multirow[t]{2}{*}{56} & Tyloses common & & \\
\hline & & $(58)$ & Gums and other deposits in vessels \\
\hline
\end{tabular}

\section{Ground tissue fibres}

61 Fibres with simple to minutely bordered pits

60 Vascular / vasicentric tracheids present

(68) Fibres very thin-walled

69 Fibres thin- to thick-walled

Cell wall thickness $6 \pm 1 \mu \mathrm{m}$

61 Fibres with simple to minutely bordered pits

65 Septate fibres present

69 Fibres thin- to thick-walled

\section{Cell wall thickness $5 \pm 1 \mu \mathrm{m}$}

71 Mean fibre lengths $<=900 \mu \mathrm{m}$

72 Mean fibre lengths $900-1600 \mu \mathrm{m}$

72 Mean fibre lengths $900-1600 \mu \mathrm{m}$

73 Mean fibre lengths $>=1600 \mu \mathrm{m}$

Mean fibre lengths $1912 \pm 299 \mu \mathrm{m}$

Mean fibre lengths $1452 \pm 176 \mu \mathrm{m}$ 
Ratih DAMAYANTI $\cdot$ Evi SRIBUDIANI $\cdot$ Sonia SOMADONA $\cdot$ Djarwanto $\cdot$ Didi TARMADI $\cdot$ Yusup AMIN $\cdot$ Sulaeman YUSUF $\cdot$ Esti Rini SATITI $\cdot$ Wa Ode Muliastuty ARSYAD $\cdot$ Rudianda SULAEMAN $\cdot$ Syafrinal $\cdot$ Dwi Ajias PRAMASARI

Table 1. (Continued)

\begin{tabular}{|c|c|c|c|}
\hline $\begin{array}{l}\text { IAWA } \\
\text { Code }\end{array}$ & \begin{tabular}{cl}
\multicolumn{1}{c}{ Balam } \\
(Macaranga conifera & (Rchb.f. \& Zoll.) Müll.Arg.)
\end{tabular} & $\begin{array}{l}\text { IAWA } \\
\text { Code }\end{array}$ & $\begin{array}{c}\text { Bintangor } \\
\text { (Calophyllum soulattri Burm.f.) }\end{array}$ \\
\hline \multicolumn{4}{|c|}{ Axial parenchyma } \\
\hline 76 & Axial parenchyma diffuse & & \\
\hline 77 & Axial parenchyma diffuse-in aggregates & & \\
\hline \multirow[t]{6}{*}{78} & Axial parenchyma scanty paratracheal & & \\
\hline & & 79 & Axial parenchyma vasicentric \\
\hline & & 80 & Axial parenchyma aliform \\
\hline & & 83 & Axial parenchyma confluent \\
\hline & & 84 & Axial parenchyma unilateral paratracheal \\
\hline & & 85 & Axial parenchyma bands more than three cells wide \\
\hline \multirow[t]{2}{*}{86} & $\begin{array}{l}\text { Axial parenchyma in narrow bands or lines up to } \\
\text { three cells wide }\end{array}$ & & \\
\hline & & 89 & $\begin{array}{l}\text { Axial parenchyma in marginal or in seemingly marginal } \\
\text { bands }\end{array}$ \\
\hline 92 & $\begin{array}{l}\text { Axial parenchyma cell type / strand length Four } \\
(3-4) \text { cells per parenchyma strand }\end{array}$ & & \\
\hline 93 & Eight $(5-8)$ cells per parenchyma strand & & \\
\hline 94 & Over eight cells per parenchyma strand & & \\
\hline \multicolumn{4}{|l|}{ Rays } \\
\hline 96 & Rays exclusively uniseriate & 96 & Rays exclusively uniseriate \\
\hline \multirow[t]{3}{*}{97} & Ray width 1 to 3 cells & 97 & Ray width 1 to 3 cells \\
\hline & & 104 & All ray cells procumbent \\
\hline & & 106 & $\begin{array}{l}\text { Body ray cells procumbent with one row of upright and } \\
\text { / or square marginal cells }\end{array}$ \\
\hline
\end{tabular}

107 Body ray cells procumbent with mostly 2-4 rows of upright and / or square marginal cells

108 Body ray cells procumbent with over 4 rows of upright and / or square marginal cells

\begin{tabular}{|c|c|c|c|}
\hline & & 109 & $\begin{array}{l}\text { Rays with procumbent, square and upright cells mixed } \\
\text { throughout the ray }\end{array}$ \\
\hline & & 115 & Rays per millimetre $4-12 / \mathrm{mm}$ \\
\hline 116 & Rays per millimetre $>=12 / \mathrm{mm}$ & 116 & Rays per millimetre $>=12 / \mathrm{mm}$ \\
\hline \multicolumn{4}{|c|}{ Prismatic crystals } \\
\hline 136 & Prismatic crystals present & 136 & Prismatic crystals present \\
\hline (137) & $\begin{array}{l}\text { Prismatic crystals in upright and / or square ray } \\
\text { cells }\end{array}$ & (137) & Prismatic crystals in upright and / or square ray cells \\
\hline$(138)$ & Prismatic crystals in procumbent ray cells & (138) & Prismatic crystals in procumbent ray cells \\
\hline$(139)$ & $\begin{array}{l}\text { Prismatic crystals in radial alignment in } \\
\text { procumbent ray cells }\end{array}$ & & \\
\hline$(140)$ & $\begin{array}{l}\text { Prismatic crystals in chambered upright and / or } \\
\text { square ray cells }\end{array}$ & & \\
\hline$(141)$ & $\begin{array}{l}\text { Prismatic crystals in non-chambered axial } \\
\text { parenchyma cells }\end{array}$ & (141) & $\begin{array}{l}\text { Prismatic crystals in non-chambered axial parenchyma } \\
\text { cells }\end{array}$ \\
\hline$(142)$ & $\begin{array}{l}\text { Prismatic crystals in chambered axial parenchyma } \\
\text { cells }\end{array}$ & & \\
\hline
\end{tabular}


perforation plates. On the other hand, Bintangor is also diffuse porous, but the vessels are exclusively solitary with simple perforation plates, and arranged in diagonals across the rays.

Balam had two types of perforation plates in its vessels namely simple and scalarifom, while Bintangor had only simple perforation plates. In its origin, vessel is not from a single cell, but a compound structure which is formed from a number of cells. It is like a pipe, sometimes a few meters in length, which the end walls of each vessel element, or vessel segment, or vessel member have disappeared. The end walls may disappear completely to form a simple perforation, alternatively, only parts of the walls may disappear with two or more opening called a multiple perforation. When the adjacent elements are then commonly separated by a grid-like plate, it is called scalarifom perforation (Jane et al., 1970). The presence of scalarifom perforation plate in Balam, compared to the only simple perforation plate in Bintangor could also contribute to the lower permeability at the axial direction in Balam. For flow of liquids, apart from the effective flow area (vessel diameter and number), and degree of occlusion, there may be an effect at vessel ends due to Balam having some scalariform perforation plates in contrast to Bintangor only having simple ones. Potentially, the bars of the former may offer some retardation to the flow compared to the simple openings of the simple perforation plates (Ilic, personal communication, May 15, 2020).

The Balam samples had wood contains tyloses but it was not observed in the Bintangor wood samples, thus the presence of tyloses in Balam added more factor inhibiting boron movement axially. Even one tyloses in a vessel will prevent flow in that vessel path (Ilic, personal communication, May 15, 2020). Tyloses are also observed in some species of Macaranga (InsideWood, 2020; Wheeler, 2011).

In longitudinal direction, the flow of fluid is mostly

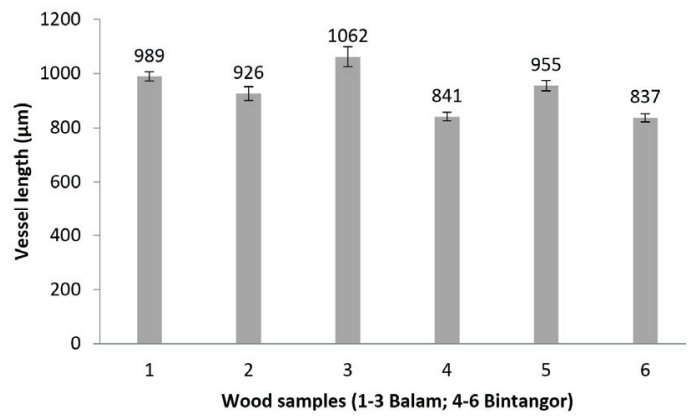

Fig. 6. Vessel length of un-treated and treated trees (preservation treatment using infusion and combination of injection and bandage-wrapping methods) of Balam (Macaranga conifera (Rchb.f. \& Zoll.) Müll.Arg.) and Bintangor (Calophyllum soulattri Burm.f.) standing trees.

Remarks: 1) Balam un-treated; 2) Balam bandaged; 3) Balam infused; 4) Bintangor un-treated; 5) Bintangor bandaged; 6) Bintangor infused.

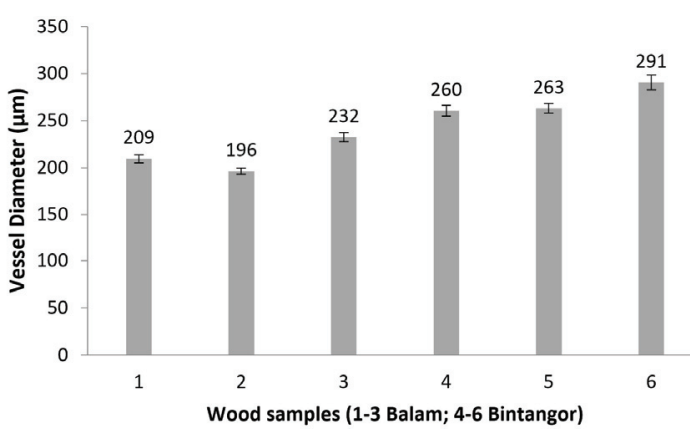

Fig. 7. Vessel diameter of un-treated and treated trees (preservation treatment using infusion and combination of injection and bandage-wrapping methods) of Balam (Macaranga conifera (Rchb.f. \& Zoll.) Müll.Arg.) and Bintangor (Calophyllum soulattri Burm.f.) standing trees.

Remarks: 1) Balam un-treated; 2) Balam bandaged; 3) Balam infused; 4) Bintangor un-treated; 5) Bintangor bandaged; 6) Bintangor infused

controlled by the dimension and number of vessels that are un-clogged by tyloses or other obstruction (Baraúna et al., 2014; Hansman et al., 2002). The average vessel diameter of Bintangor was significantly larger than Balam (Fig. 7), while the vessel length were shorter (significantly different at control and in- 
Ratih DAMAYANTI $\cdot$ Evi SRIBUDIANI $\cdot$ Sonia SOMADONA $\cdot$ Djarwanto $\cdot$ Didi TARMADI $\cdot$ Yusup AMIN $\cdot$ Sulaeman YUSUF $\cdot$ Esti Rini SATITI $\cdot$ Wa Ode Muliastuty ARSYAD $\cdot$ Rudianda SULAEMAN $\cdot$ Syafrinal $\cdot$ Dwi Ajias PRAMASARI

fused tree samples), Fig. 6. Vessel frequency in Balam wood (in average was seven vessel per square millimetre) was higher than Bintangor (in average was four vessel per square millimetre), however, the higher vessel frequency in Balam wood generally did not contribute to the higher penetration of boron. Remember that this is not the only governing factor; it is the combination of size and number of vessel namely the effective cross-sectional area (Ilic, personal communication, May 15, 2020). In this study, even though the number of vessel per $\mathrm{mm}^{2}$ in Balam was higher, but the presence of tyloses may more significant.

Balam had more complex vessel-ray pitting than Bintangor, but the structure of rays mainly the width and frequencies were almost uniform. According to Emaminasab et al. (2017), in the study of the permeability of normal and tension wood in poplar, the frequency of rays did not play role in radial fluid, but the inter-vessel and vessel-ray pitting was more essential. The differences in vessel structure of Balam and Bintangor as explained above were more dominant causing the lower penetration of wood preservative in Balam wood (Fig. 4).

In axial direction, the wood preservative moved down to the tree base, and moved up following the tree-sap movement through vessels. Vessel is conducting element, convey of water and dissolved mineral salt from the soil (roots) to the leaves of the trees (Bowyer et al., 2003; Jane et al., 1970; Panshin et al., 1964). Hence, to obtain more penetration in whole part of the log, the treatment should be applied at very low position in trees.

\section{CONCLUSION}

The combination of bandage-wrapping and infusion method, or alternatively by infusing the living trees close to the bark and at very low position in the tree stem is recommended to be applied in preserving li- ving trees. The influences of wood anatomical structure were investigated. The result showed that the perforation plates between vessels, the dimension of vessel, and the presence/absence of tylosis contributed to the permeability of wood for preservative treatment. The more simple perforation plates, larger vessel diameter, and the absence of tylosis gave higher penetration of wood preservative.

\section{ACKNOWLEDGMENT}

Thank you to the Directorate of Industrial Technology Development (PPTI) Ministry of Research and Technology the Republic of Indonesia for giving the research funding through the 2019 National Innovation System Research Incentive (INSINAS) Program. Thanks are also directed to Kepala Kesatuan Pengelolaan Hutan Minas TAHURA Riau, Datuk in Hutan Larangan Adat Rumbio, all students, and research assistants. High appreciation is dedicated to Prof. Jugo Ilic, Australian Wood Anatomist, who has been reviewed and gave many valuable inputs to this manuscript. All authors are main contributor.

\section{REFERENCES}

Abdurrohim, S., Mandang, Y., Sutisna, U. 2006. Atlas Kayu Indonesia, Jilid III [Indonesian Wood Atlas Vol. III], Pusat Penelitian dan Pengembangan Hasil Hutan (Forest Products Research and Development Centre), Bogor, Indonesia.

Arsyad, W.O.M., Basri, E., Hendra, D., Trisatya, D.R. 2019. Termite resistance of impregnated jabon wood (Anthocephalus cadamba Miq.) with combined impregnant agents. Journal of the Korean Wood Science and Technology 47(4): 451-458. Baraúna, E.E.P., Lima, J.T., Vieira, R.D.S., Silva, J.R.M.D., Monteiro, T.C. 2014. Effect of anatomical and chemical structure in the permeability of 
The Movement of Boron Compound by Infusion Method and Combination of Injection and Bandage-Wrapping

“Amapá” wood. CERNE (20): 529-534.

Barnacle, J., Ampong, F. 1974. Refractory intermediate wood in round teak fence posts. Ghana Journal of Science 14(2): 193-198.

Basri, E., Yuniarti, K., Wahyudi, I., Saefudin, Damayanti, R. 2015. Effects of girdling on wood properties and drying characteristics of Acacia mangium. Journal of Tropical Forest Science 27(4): 498-505.

Bowyer, J., Shmulsky, R., Haygreen, J. 2003. Forest Products and Wood Science an Introduction, 4th ed., Iowa: Iowa State Press (Blackwell Publishing Company).

Cahyono, T.D., Darmawan, W., Priadi, T., Iswanto, A.H. 2020. Flexural properties of heat-treatment Samama (Anthocephalus macrophyllus) wood impregnated by Boron and Methyl Metacrylate. Journal of the Korean Wood Science and Technology 48(1): 76-85.

Damayanti, R. 2016. Wood quality of young fast grown plantation teak and the relationships among ultrastructural and structural characteristics with selected wood properties. Ph.D. Thesis. The University of Melbourne, Melbourne.

Damayanti, R. 2019. Struktur anatomi Trema orientalis Blume - Ulmaceae. in Supriyanto, Mindawati, N. and Lisnawati, Y., (eds.) Bunga rampai prospek pengembangan Trema orientalis sebagai alternatif pengganti sengon. Bogor: IPB Press, pp. 22.

Djarwanto, Sudradjat. 2002. Pengawetan kayu mangium secara rendaman panas-dingin dengan bahan pengawet Boron dan CCB. Buletin Penelitian Hasil Hutan 20(1): 12-19.

Ellwood, E., Ecklund, B. 2020. Wood Permeabilty. Available: https://ir.library.oregonstate.edu/xmlui/ bitstream/handle/1957/4869/Perm_Wood_ocr.pdf. [Accessed 5 May 2020].

Emaminasab, M., Tarmian, A., Oladi, R., Pourtahmasi, K., Avramidis, S. 2017. Fluid permeability in poplar tension and normal wood in relation to ray and vessel properties. Wood Science Technology, March. Fadillah, A.M., Hadi, Y.S., Massijaya, M.Y., Ozarska, B. 2014. Resistance of preservative treated mahogany wood to subterranean termite attack. Journal of the Indian Academy of Wood Science 11(2): 140-143.

Forestry Education Web Service. 2020. Preservation of timber. Available: http://www.timber.lk/PRASE RVATION/Wood-preservation-process/index.html \# [Accessed 5 May 2020].

Hadi, Y.S., Massijaya, M.Y., Zaini, L.H., Abdillah, I.B., Arsyad, W.O.M. 2018. Resistance of methyl methacrylate-impregnated wood to subterranean termite attack. Journal of the Korean Wood Science and Technology 46(6): 748-755.

Hansman, C., Gindl, W., Wimmer, R., Boku, A.T. 2002. Permeability of wood - A review. Wood Research, 47(4): 1-16.

Hillis, W. 1987. Heartwood and Tree Exudates to Springer Series in Wood Science. Springer-Verlag, Berlin Heidelberg Germany.

InsideWood. 2020. Published on the Internet. http://insidewood.lib.ncsu.edu/search [Accessed 9 May 2020].

Jane, F., Wilson, K., White, D. 1970. The Structure of Wood, Second ed., London: A. and C. Black Ltd.

Kartal, S., Hwang, W., Imamura, Y. 2008. Combined effect of boron compounds and heat treatments on wood properties: Chemical and strength properties of wood. Journal of Materials Processing Technology 198(1-3): 234-240.

Martawijaya, A., Kartasujana, I., Kadir, K., Prawira, S. 2005. Atlas Kayu Indonesia Jilid II [Indonesian Wood Atlas Vol. II], Pusat Penelitian dan Pengembangan Hasil Hutan (Forest Products Research and Development Centre), Bogor, Indonesia.

Obanda, D.N., Shupe, T.F., Barnes, H.M. 2008. Reducing leaching of boron-based wood preservatives 
Ratih DAMAYANTI $\cdot$ Evi SRIBUDIANI $\cdot$ Sonia SOMADONA $\cdot$ Djarwanto $\cdot$ Didi TARMADI $\cdot$ Yusup AMIN $\cdot$ Sulaeman YUSUF Esti Rini SATITI $\cdot$ Wa Ode Muliastuty ARSYAD $\cdot$ Rudianda SULAEMAN $\cdot$ Syafrinal $\cdot$ Dwi Ajias PRAMASARI

- A review of research. Bioresource Technology 99(15): 7312-7322.

Pang, S.-J., Oh, J.-K., Lee S.-J., Park, J.-H., Jang, S.-I., Lee, J.-J. 2017. Surface checking reduction effect of preservative-treated Korean larch round-woods with various physical treatments. Journal of the Korean Wood Science and Technology 45(1): 107-115.

Panigrahi, S., Kumar, S., Panda, S., Borkataki, S. 2018. Effect of permeability on primary processing of wood. Journal of Pharmacognosy and Phytochemistry 7(4): 2593-2598.

Panshin, A., Zeeuw, C.D., Brown, H. 1964. Textbook of Wood Technology. Volume I: Structure, identification, uses, and properties of the commercial woods of the United States. McGraw-Hill Book Company, New York.

Ra, J. 2019. Ten-year performance of shell-treated wooden deck. Journal of the Korean Wood Science and Technology 47(6): 667-673.

Rabbi, M.F., Islam, M.M., Rahman, A.N.M.M. 2015. Wood preservation: Improvement of mechanical properties by vacuum pressure proces. International Journal of Engineering and Applied Sciences 2(4): $75-79$.

Seng, O.D. 1990. Berat jenis dari jenis-jenis kayu Indonesia dan pengertian beratnya kayu untuk keperluan praktek (Specific gravity of Indonesian woods and its significance for practical use). Pusat
Penelitian dan Pengembangan Hasil Hutan (Forest Products Research and Development Centre), Bogor.

Soerianegara, I., Lemmens, R. 1994. Plant Resources of South-East Asia 5 (1). Timber trees: Major commercial species, Plant Resources of South-East Asia. Backhuys Publisher, Leiden.

Sosef, M., Hong, L., Prawirohatmodjo, S. 1998. Plant Resources of South-East Asia 5 (3). Timber trees: Lesser-known timbers. Plant Resources of SouthEast Asia.: Backhuys Publisher, Leiden.

Sribudiani, E., Somadona, S., Sulaeman, R., Syafrinal, Yusuf, S., Amin, Y., Tarmadi, D., Pramasari, D.A., Damayanti, R., Djarwanto. 2019. Sifat fisis kayu berkualitas rendah dari Riau setelah melalui proses pengawetan pohon dengan teknik bandage dan infus (Physical properties of low-quality timber from Riau after through trees processing with bandage and infusion techniques). Wahana Forestra: Jurnal Kehutanan 14(2): 30-37.

Walker, J., Butterfield, B., Langrish, T., Harris, J., Uprichard, J. 1993. Primary wood processing: Principles and Practice. Chapman \& Hall, London.

Wheeler, E., Baas, P., Gasson, P. 1989. IAWA list of microscopic features for hardwood identification. IAWA Bulletin 10(3): 219-332.

Wheeler, E. 2011 InsideWood- a web resource for hardwood anatomy. IAWA Journal 32(2): 199-211. 